\title{
IBM, Elsevier Science, and Academic Freedom
}

\author{
JOHN C. BAILAR, III, PHD, ANDRE CICOLELLA, DIPL ENG, ROBERT HARRISON, MD, MPH, \\ JOSEPH LADOU, MD, BARRY S. LEVY, MD, MPH, TIMOTHY ROHM, PHD, CIH, \\ DANIEL T. TEITELBAUM, MD, YUNG-DER WANG, MD, PHD, ANDREW WATTERSON, PHD, \\ FUMIKAZU YOSHIDA, PHD
}

\begin{abstract}
Elsevier Science refused to publish a study of IBM workers that IBM sought to keep from public view. Occupational and environmental health $(\mathrm{OEH})$ suffers from the absence of a level playing field on which science can thrive. Industry pays for a substantial portion of $\mathrm{OEH}$ research. Studies done by private consulting firms or academic institutions may be published if the results suit the sponsoring companies, or they may be censored. OEH journals often reflect the dominance of industry influence on research in the papers they publish, sometimes withdrawing or modifying papers in line with industry and advertising agendas. Although such practices are widely recognized, no fundamental change is supported by government and industry or by professional organizations. Key words: Elsevier; industry influence; research; academic freedom.
\end{abstract}

INT J OCCUP ENVIRON HEALTH 2007;13:312-317

$\mathrm{I}$ n 1985, a chemist working in the Material Analysis Department at the IBM research facility in San Jose, California, wrote a memo to IBM Corporate Headquarters, alerting IBM officials to a cluster of cancers that his colleagues had experienced. ${ }^{1}$ Among the group of 12 workers in a research and development laboratory, two had died of brain cancer, two had died of lymphatic cancer, and two had died of gastrointestinal cancers. When two more developed bone tumors and the group's leader later died of brain cancer, the survivors pressed hard to bring IBM's attention to the issue. Gary Adams, the author of the memo, said the response of a staff doctor to his request that the company monitor its workers' health had been to say such a program would be a waste of time, because "workers did not get cancer from their jobs."

IBM commissioned a study of brain cancer mortality among electronics workers, to be conducted by Beall and Delzell at the University of Alabama, Birmingham (UAB). ${ }^{3}$ The UAB investigators under contract to IBM

Address correspondence and reprint requests to: Dr. Joseph LaDou, e-mail: <joeladou@aol.com>. have had considerable experience in conducting industry-supported research over many years. The IBM Corporate Mortality File cited in the study report recorded deaths for virtually all U.S. IBM employees from 1969 to 1995 . The study was reported in 1996, more than a decade after the Adams memo was submitted to management. The study prompted the authors to state that, "Information about specific exposures in the work environment, such as EMF, ionizing radiation, or chemical agents, was not available. Some of the observed associations are difficult to interpret because exposure information pertaining to division and job groups is lacking." "The UAB study found that mortality from brain cancer among male electronics workers increased as the duration of employment in "technical jobs" lengthened. This was consistent with a trend previously reported, that the risk of dying from brain cancer is highest among electrical and electronics workers with long-term work histories-specifically, those of ten years or more-and with probable exposures to solders and organic solvents. ${ }^{4}$ The earlier study found that the risk of astrocytic tumors among electronics manufacture and repair workers was increased tenfold among those employed for 20 years or more.

\section{INDUSTRY-SPONSORED RESEARCH}

The problem of industry sponsorship of research is not new. The National Institute for Occupational Safety and Health (NIOSH) budget has provided less research and training funding to occupational health and safety with each succeeding year, while at the same time funds for biomedical research and education are increased. Conversely, private commercial funding of university research has expanded dramatically over the past decades. Such funding has grown to more than $\$ 2$ billion annually, making U.S. universities more dependent on private commercial funding than ever before. ${ }^{5}$ The extent of corporate-funded science is troubling because, as Egilman and Rankin-Bohme have pointed out, industry funding is accompanied by a "substantial tradition of manipulation of evidence, 
data, and analysis, ultimately designed to maintain favorable conditions for industry, at both the material and ideological levels." 6

James Huff of the National Institute of Environmental Health Sciences (NIEHS) recently summarized the current state of affairs by pointing out that the

Traditional covert influence of industry on occupational and environmental health policies has turned brazenly overt in the last several years. More than ever before the occupational and environmental health community is witnessing the perverse influence and increasing control by industry interests. Industry hires academic experts to support their position, however tenuous and speculative, to endorse their products and to explain and downplay the risks to government and in public forums.

Huff named many of the nation's scientists who participate in these activities, specifically identifying Coleen Beall, and Elizabeth Delzell of UAB. ${ }^{7}$

\section{IBM ON TRIAL}

In 2003, a suit against IBM involving two plaintiffs with cancer, James Moore (with non-Hodgkin's lymphoma) and Alida Hernandez (with breast cancer), came before a jury in San Jose, California. In the course of legal discovery, attorneys for the plaintiffs asked for employee records. The court granted access to the same Corporate Mortality File that IBM had provided to $\mathrm{UAB}$ investigators for their earlier study. ${ }^{3}$ IBM attempted to block plaintiffs' attorneys access to the file, maintaining that it contained no helpful data, but was overruled.

Once access was granted, attorneys for the plaintiffs asked epidemiologists Richard Clapp of Boston University School of Public Health and Rebecca Johnson of Epi Center, Inc., to study the IBM Corporate Mortality File. Clapp and Johnson found patterns of mortality in the IBM workforce consistent with occupational exposures to solvents and other carcinogenic materials used in IBM manufacturing processes. The files contained data on decedents between 1969 and early 2001. The final number of records used for analysis, 31,961, included records for 27,288 males and 4,673 females. There had been 7,703 cancer deaths in men, where 7,208 would have been expected $(\mathrm{PMR}=106.9 ; 95 \% \mathrm{CI}$ $=104.9-108.9,99 \% \mathrm{CI}=104.2-109.6)$. Among the females there were 1,668 cancer deaths, compared with 1,455 expected $(\mathrm{PMR}=114.6 ; 95 \% \mathrm{CI}=110.3-119.2$; 99\% CI $=108.9-120.6)$. Proportionate mortality ratios (PMRs) for all sites were found to be significantly elevated when the IBM workers were compared with the U.S. population. There was excess mortality in IBM males due to cancers of the large intestine, pancreas, kidney, testis, thyroid, central nervous system, and all lymphatic and hematopoietic tissues, and melanoma.
In females, there was excess mortality due to cancers of the lungs and bronchus, breast, other female organs, and central nervous system, and all lymphatic and hematopoietic tissues. The types of cancers that increased the most were consistent with the findings of other studies of semiconductor workers and studies of workers in other industries exposed to the same chemicals. Key findings were the excess deaths due to brain, breast, kidney, lymphatic, and hematopoietic cancers and melanoma. ${ }^{8,9}$

After pretrial hearings and a review of Clapp's declarations, Judge Robert A. Baines ruled that the analysis of IBM's Corporate Mortality File data contained in Dr. Clapp's public Court declarations was inadmissible as evidence in the trial: "This same study, again, assuming that it is a valid study, could be used to show any number of things, such as if . . . everyone in manufacturing drank coffee in the company cafeteria ... coffee served in the company lunch-room causes cancer." ${ }^{10}$

In an editorial in Science, Donald Kennedy stated that, "The judge refused to admit these findings, calling them irrelevant and prejudicial, thus combining a scientific judgment with a legal one." 11 IBM executive Scott R. Brooks responded with a letter stating that

It is disturbing that a reputable journal like Science would allow itself to be used as a mouthpiece for litigation advocates whose position seems to be that 'academic freedom' trumps court orders and justifies misappropriation of data, and that litigationgenerated studies of woefully inadequate and incomplete data are a valuable contribution to scientific knowledge. Your readers deserved better." 12

The comments by the judge and by IBM cannot be justified. Clapp and Johnson's analysis helped establish associations between work at IBM and the development of some cancers, crucial to the plaintiffs' case, given that IBM has consistently denied any such association. The analysis also revealed that IBM had failed to disclose evidence of risks to IBM workers, while at the same time maintaining a Corporate Mortality File that included relevant data and was the best available dataset from which to determine whether the claims by the plaintiffs against IBM were correct. Given that the premise of the plaintiffs' claim was corporate fraud and concealment (one of the few bases for workers to sue their employers rather than be limited to no-fault workers' compensation as a remedy), exclusion of these data from the jury's deliberations was of critical importance. After losing the case, a plaintiffs' attorney said that the prohibition of using Clapp's analysis of IBM's Corporate Mortality File data in the trial had meant that, "I fought the case with one hand tied behind my back." 13 Soon thereafter, IBM announced that it had settled all the outstanding lawsuits with over 50 current and former California workers for an undisclosed sum. 


\section{IBM AND ACADEMIC FREEDOM}

In a move that upset IBM, Clapp submitted his analysis for inclusion in a special issue of the scholarly journal, Clinics in Occupational and Environmental Medicine, devoted to the electronics industry. IBM lawyers sent a letter cautioning Clapp not to publish the details of his analysis, stating that it was protected by a court order guaranteeing its confidentiality-despite the public availability of Clapp and Johnson's overall findings in court records. ${ }^{14,15}$

In normal circumstances, the matter would have ended there, but Clapp was not finished. He called Joe LaDou who was Guest Editor of the Clinics special issue to report that he had engaged a private attorney, who had advised him that he could proceed with the planned publication. According to his lawyer, Indira Talwani, of Segal, Roitman \& Coleman, in Boston, Clapp had the legal right to publish his research findings. One basis for her conclusion was that, for all their sword-rattling after the fact, IBM's lawyers had failed to seal a lengthy deposition taken in the San Jose case that contained his analyses as marked exhibits. Furthermore, the controversial paper was in the public domain, with some of its findings being cited in the New York Times in columns by Bob Herbert. ${ }^{16,17}$

As news of Clapp's temerity became public, IBM lawyers went beyond the statement of legal prohibitions, becoming increasingly strident with their comments to the media. The Wall Street Journal reported that IBM lawyers labeled the analysis "junk science." 18 Robert Weber, the lead defense counsel in the San Jose case, carried the slur to its extreme, asserting that the Clapp study, "gives junk science a bad name." ${ }^{19}$ Robert Weber is now a senior executive at IBM, having left the Jones \& Day law firm.

In a letter to Science, IBM's Scott R. Brooks said that Clapp's data are, "incomplete and inadequate for reliable study." 18 Clapp disputed this by saying that the data he received from IBM were close to $100 \%$ complete, and that IBM's own research contractors at UAB had published a previous article using the same dataset. ${ }^{20}$ One of IBM's attorneys, from the Washington, D.C., office of Jones \& Day, said that, "It is a phony, litigation-driven study," adding, "This isn't peerreviewed, it isn't published, and it wouldn't qualify for publication in any legitimate scientific journal." 10

The case was widely reported in the news media, as were some of the findings of the Clapp and Johnson study, leading IBM to respond that, "In a workforce as large as IBM's, many workers will, by simple chance, contract unusual diseases." 21 "There's no evidence that any workers' illnesses were caused by their work at IBM."22 New York Times columnist, Bob Herbert, wrote that, "Representatives of IBM have said there's no evidence anyone has died from chemical exposure in the workplace and, in background conversations, have spoken venomously about the motives and tactics of the lawyers and others who have gone to bat for the plaintiffs." 17

IBM lawyers warned Clapp that publishing the paper would violate a court order specifying that the internal IBM data be used only in litigation. IBM spokesman Scott R. Brooks denies that IBM blocked Clapp's study. He is correct that IBM never went to court to block it. But in March 2004, in a letter to plaintiffs' attorney Steven Phillips, IBM attorney Michael Templeton wrote that publication of the study would represent "a misappropriation of data that Dr. Clapp has no right to use for such purposes," and that "IBM expressly reserves all of its rights to take any appropriate action." ${ }^{12}$ Clapp's attorney, Indira Talwani, calls that "a threat." Brooks maintains that publishing the study would violate four court orders; Talwani, in contrast, maintains that the study is in the public domain. Clapp, after withdrawing his submission, told Science that if he hadn't received the letter from IBM's lawyers, he would have gone ahead and published the study in Clinics. ${ }^{22}$

\section{IBM RETALIATES}

While successfully delaying the publication of the Clapp study, IBM retained epidemiologists at the University of Alabama who had conducted their prior cancer study ${ }^{3}$ to do a further study of cancer risk among workers at two IBM plants. Workers were evaluated for cause-specific mortality rates compared with general population rates. ${ }^{23}$ The healthy-worker effect was evident in the lower-than-expected overall mortality, but brain cancer was again associated with semiconductor exposures, despite the fact that the workforce was divided into many subgroups that made it difficult to analyze individual cancer risks. No apparent effort was made to utilize the company's industrial hygiene records of worker exposures to a number of carcinogens. ${ }^{24}$

In November 2004, the IBM Medical Director sent a message to employees that was simultaneously released to the public. The message began, "Safeguarding employee health, safety and well-being in the workplace is core to our values and woven into every aspect of who we are as a company. This includes rigorously evaluating our business practices and work environments." ${ }^{25}$ The message went on to state that preliminary evidence from the UAB study revealed that IBM employees had fewer cancers than expected. The IBM Medical Director failed to mention that the study showed that length of employment was associated positively with brain cancer among IBM workers. Other cancers with increased relative risks were leukemia, non-Hodgkin's lymphoma, ovarian cancer, and prostate cancer.

The same group of UAB researchers then published another paper as an additional investigation focused on cancer incidence rather than on mortality. The study excluded one of the IBM facilities included in the 
earlier study because it was "not feasible" to link with the Vermont cancer registry for data on the Burlington facility. They compared the incidence rates of cancer for 89,054 men and women workers at IBM facilities in East Fishkill, New York, and San Jose, California, with general population rates. Employees had total cancer incidence rates that were lower than the general population rates overall and those of subgroups with many years since starting work and relatively long durations of employment.

These deficits reflected employees' low incidence rates of most cancers related to smoking, alcohol and nutritional deficits. When compared with the general population, some employee subgroups had small increases in several cancers, including melanoma of the skin and cancers of the colon, breast, prostate, and thyroid. ${ }^{26}$

The researchers begin their paper by stating that "Because it was not known whether semiconductor workers have been exposed to carcinogenic agents and because previous epidemiological studies have not provided evidence that exposures in the industry are associated with cancer, we did not evaluate hypotheses on specific agents and cancers as part of the present research." They end the paper by concluding that, "The results of the study do not provide any strong evidence of a causal association between employment factors and cancer." 26

In a Commentary in the same journal issue, K. A. Mundt of ENVIRON International Corporation (a global consulting firm used extensively by industry), summarized the new study with the following comments

Although reporting a few excesses of specific cancers, some of which may be expected owing to random error, the study offers some reassurance that at this stage of follow-up no noteworthy increases in cancer risk are seen among employees . . the study of the IBM semiconductor and storage device workers seems to be negative. ${ }^{27}$

\section{Clapp responded}

I believe Mundt is being too quick here to minimize the cancer risk in the semiconductor industry. He gives an interpretation that is even more cautious than the IBM consultants who did the study. Bender, et al. at least point out that there were several excesses that seemed to be related to exposure periods in the earliest part of the follow-up. They also note that some of the incidence findings mirror the findings of a previously published mortality study; they cite the excess of brain cancer cases in maintenance and repair workers in East Fishkill, for example, a finding similar to the excess brain cancer mortality in workers in this job group.

Clapp further noted,
Neither Mundt nor Bender, et al. discuss the implications of the timing of the cancer incidence study. Because of the period of operation of the state cancer registries in New York (1976 and after) and California (1988 and after), and the period of follow-up of the cohort, the study looked at a later time interval than the mortality study by Beall, et al. (2005); that study included deaths in the period 1965-1999 for workers in both states. My own study on cancer in IBM employees covered deaths in the period 1969-2001, and I was able to look at patterns in five-year intervals and it was clear that the excess cancer deaths were predominantly in the earlier years: 1969-1979 in females, and 1969-1989 in males in the IBM workforce. In fact, in males, there was almost no overall excess cancer mortality after 1990. So, to the extent that the incidence data captured patterns in California from 1988 onward, this was the period of little or no excess mortality and likely the least informative potential work-related risks. It's like looking for the horse after it had already run out of the barn. Mundt's assurances that the remaining risks are small and that not much can be learned by further studies in this industry are premature. ${ }^{28}$

\section{ELSEVIER SCIENCE AND ACADEMIC FREEDOM}

Dr. Clapp again called Joe LaDou in his role as Guest Editor of the Clinics issue to tell him that the Boston University legal department had advised him that he could proceed with the submission. Their position was that the paper was in the public domain. LaDou submitted the paper to Elsevier Science, publishers of Clinics, and shortly thereafter received a message from Catherine Bewick of Elsevier stating that, "I expect to be speaking with my legal department next week after their review of the situation and I will get back to you then." ${ }^{29}$ Shortly thereafter she sent LaDou a brief message, "It has been decided that we will not be able to publish the paper by Drs. Clapp and Johnson as it is an original research article and the Clinics in Occupational and Environmental Medicine publish only review articles." ${ }^{30}$ Elsevier made the same assertion to the media and at scientific meetings in the months that followed. ${ }^{18}$ Nothing in Elsevier's instructions to Guest Editors (at that time) precluded articles with original research. A review of the Clinics issues for the two years preceding the proposed special issue on the electronics industry reveals six original research studies. ${ }^{31-36}$

Elsevier spokesperson Eric Merkel-Sobotta, when asked whether IBM had contacted Elsevier about the study, said, "There's been no coercion and no threats." Elsevier said its decision had nothing to do with fears that IBM might pursue legal action against the publisher. ${ }^{37}$ IBM spokesperson Chris Andrews said that IBM "has not contacted anyone with regards to Clapp's intent to publish." 15 Morris Greenberg, a revered and distin- 
guished occupational physician, remarked that the question asked was, "Did IBM contact Elsevier about the study? A nod is as good as a wink to a blind horse, and threats are unnecessary when the media are prepared to apply self censorship rather than make waves." 38

Academic freedom requires access to publication for scientific studies whether a journal publisher likes the content or not. If the material is worthy, and the editor is satisfied the piece meets the journal's scientific standards, the publisher's interference smacks of censorship or pandering to its advertisers or sponsors. Elsevier censored the Clapp and Johnson paper after Boston University indicated it would back these authors in all necessary ways.

After obtaining written permission from all 13 authors submitting articles to the special issue on electronics, we wrote to Elsevier stating that, "We are hopeful that Clapp and Johnson will be successful in placing their article in another journal, or in yours if Elsevier will reconsider its position. We will publish when they publish, wherever that may be. We are standing together with Clapp and Johnson." 39

The Clinics boycott is only the latest in a series of censorship disputes involving Elsevier. Recently, 40 scientists accused another Elsevier journal, Regulatory Toxicology and Pharmacology, of "corporate conflicts of interest, lack of transparency, and absence of editorial independence." The scientists also contended that the journal "serves as a convenient venue for the publication of industry research." The journal had published papers paid for by the tobacco industry without revealing this sponsorship and had published numerous other papers by paid consultants for various industries without revealing those links. ${ }^{40}$

\section{THE FINAL DECISION}

In March 2006, after more than two years of intimidation and delaying tactics by IBM, plaintiffs in New York got that state's court to declare the Clapp and Johnson study non-confidential. That motion removed any residual basis for objection to publication of Clapp and Johnson's detailed study. The court in New York issued an injunction prohibiting IBM from interfering with Dr. Clapp's efforts to publish his corporate mortality study. Accordingly, Dr. Clapp submitted his paper and it was accepted and subsequently published in the peerreviewed journal Environmental Health. ${ }^{41}$ The article has been accessed over 30,000 times since its publication.

Shortly after the Clapp study was published, Chris Andrews, a spokesman for IBM, told The Scientist Clapp's findings "aren't credible, nor are they backed by any kind of legitimate science." According to Andrews, the Corporate Mortality File was an "incomplete human resources database that IBM used years ago in conjunction with providing benefits to beneficiaries of deceased IBM employees. It really contained no information that would support the study of and the drawing of scientifically valid conclusions with regard to diseases among IBM workers." ${ }^{42}$ IBM spokesman Andrews again used the damaging slur that "the latest study has been discredited as 'junk science' and that other research has shown there is no link. This is propaganda and a fear-driven effort," referring to the report and renewed efforts by some former employees to raise health concerns. "It's something we take seriously. Our priority is to work to the highest level of employee safety. But it's reasonable to say there are individuals who have historically drummed up this concern." ${ }^{43}$

John Greenagel, a lay spokesman for the Semiconductor Industry Association, said that "the proportional mortality ratio design of Clapp's study was not a valid approach to evaluating cancer risks." ${ }^{42}$ Greenagel told USA Today that, "There has not been one scientifically valid study to show a link to cancer." He said that concerns about health issues are in part being drummed up by organizations seeking to unionize workers. "There have been activist groups for years. Their major beef is we're a non-union industry." 43

\section{CONCLUSION}

The past two years of legal delays gave IBM and its consultant epidemiologists the opportunity to conduct and publish favorable studies of the IBM Corporate Mortality File, and to present the results in the most acceptable manner possible to IBM employees and to the public. During this time, IBM lost no opportunity to challenge and to denigrate independent attempts to assess its commitment to occupational health and safety.

The actions of IBM and of Elsevier Science point up the need for speedy government action to obtain nonindustry-funded studies of many workplace hazards and a wider commitment of all journals, editors, and their publishers to ensure that important research findings that may affect public health or social justice reach both the scientific community and the public as rapidly as possible.

\section{References}

1. Adams G. Letter to Stan R. Ciraulo, General Manager, IBM Corporation, September 29, 1996.

2. Fisher J. Cancer in the semiconductor industry [editorial]. Arch Environ Health 2002;57:95-7.

3. Beall C, Delzell E, Cole P, Brill I. Brain tumors among electronics industry workers. Epidemiology. 1996;2:125-30.

4. Thomas TL, Stolley PD, Stemhagen A, et al. Brain tumor mortality risk among men with electrical and electronics jobs. J Natl Cancer Inst. 1987;2:233-8.

5. Washburn J. University, Inc: The Corporate Corruption of Higher Education. New York: Basic Books, 2005.

6. Egilman DS, Rankin Bohme S. Over a barrel: corporate corruption of science and its effects on workers and the environment. Int J Occup Environ Health. 2005;11:331-7.

7. Huff J. Industry influence on occupational and environmental public health. Int J Occup Environ Health. 2007;13:107-17.

8. Clapp RW. Declaration of Richard Clapp, D.Sc., in Support of Plaintiffs Opposition to IBM's Motion for Summary Judgment. 
In re: San Jose Workers litigation, Master Case No. CV 772093; Superior Court of the State of California, in and for the County of Santa Clara. Endorsed and filed September 12, 2003.

9. Clapp RW. Declaration of Richard Clapp in Support of Motion for Reconsideration re Exclusion of Richard Clapp's Corporate Mortality file analyses. In re: San Jose Workers litigation, Master Case No. CV 772093; Superior Court of the State of California, in and for the County of Santa Clara. Endorsed and filed October 2, 2003.

10. Regalado A, Bulkeley, WM. IBM cancer data fuel debate over publication. Wall Street Journal, June 24, 2004: B1.

11. Kennedy D. Science, law, and the IBM case [editorial]. Science. 2004;305:309.

12. Brooks SR. A response from IBM [letters]. Science. 2004;305-40.

13. Bulkeley WM. IBM settles workers' cancer claims. Wall Street Journal, June 24, 2004: B4.

14. Ferber D. Beset by lawsuits, IBM blocks a study that used its data. Science (Occupational Medicine). 2004;304:937-9.

15. Wadman M. Scientists cry foul as Elsevier axes paper on cancer mortality. Nature. 2004;429:687.

16. Herbert B. Sick and suspicious. New York Times. September 4, 2003. <http://www.nytimes.com/2003/09/04/opinion/ 04HERB.html? ex $=1063658096 \& \mathrm{cei}=1 \& \mathrm{cen}=246 \mathrm{fb} 1152 \mathrm{c} 68 \mathrm{f} 4 \mathrm{f9}>$.

17. Herbert B. Clouds in Silicon Valley. New York Times. September 8, 2003. <http://www.nytimes.com/2003/09/08/opinion/ 08HERB.html? ex $=1064003780 \&$ ei $=1 \& \mathrm{cen}=2 \mathrm{a} 8 \mathrm{a} 8 \mathrm{~cd} 4066 \mathrm{c} 3 \mathrm{c} 7 \mathrm{a}>$.

18. McCook A. IBM responds in study dispute in Science, the company says data for worker mortality study were inadequate. The Scientist. July 16, 2004.

19. Cutler JE. Court's protective orders bars researchers from publishing studies in IBM case. Toxic Torts. 2004;19:575.

20. McCook A. Researchers boycott journal: contributors cry foul play after the publisher refuses to include a controversial article. The Scientist. June 23, 2004. <http://www.biomedcentral.com/ news $/ 20040623 / 04 />$.

21. McKie R. IBM fights to suppress cancer probe. Computer giant accused of persuading scientific journal to block academic investigation of illness in employees. The Observer. June 20, 2004. <http://www.guardian.co.uk>.

22. Ferber D. Reply to Letter by SR Brooks of IBM [letter]. Science. 2004;305-42.

23. Beall C, Bender TJ, Cheng H, et al. Mortality among semiconductor and storage device-manufacturing workers. J Occup Environ Med. 2005;47:996-1014.

24. Herrick RF, Stewart JH, Blicharz H, et al. Exposure assessment for retrospective follow-up studies of semiconductor- and storage device-manufacturing workers. J Occup Environ Med. 2005; 47:983-95

25. Sepulveda M. Health study information. Message sent to IBM employees by Chris Andrews, Media Relations Manager, Technology, IBM Systems \& Technology Group, November 4, 2004.

26. Bender TJ, Beall C, Cheng H, er al. Cancer incidence among semiconductor and electronic storage device workers. Occup Environ Med. 2007;64:30-6.

27. Mundt KA. Cancer risk in the semiconductor industry: responding to the call for action. Occup Environ Med. 2007;64:5-6.
28. Clapp R. Rush to judgement: Industry consultant too quick to give IBM a clean bill of health. The Pump Handle. $<$ http:/ the pumphandle.wordpress.com/2007/01/03/rush-to-judgementindustry-consultant-too-quick-to-give-ibm-a-clean-bill-ofhealth/\#more-70>.

29. Bewick C. Internet message from Catherine Bewick of Elsevier Science to Joe LaDou, May 27, 2004

30. Bewick C. Internet message from Catherine Bewick of Elsevier Science to Joe LaDou, June 6, 2004.

31. Utzinger J, Wyss K, Moto DD, Tanner M, Singer BH. Community Health Outreach of the Chad-Cameroon Petroleum Development and Pipeline Project. Clin Occup Environ Med. 2004;4(1): 9-26. [Original research supported by Swiss National Science Foundation, Princeton University, and the Swiss Tropical Institute.]

32. Martin A, Baptiste JP, Krieger G. Respiratory infections: SARS and tuberculosis. Clin Occup Environ Med. 2004;4(1):189-204. [Original research, a cross-sectional study conducted in N'Kjamena General Hospital, Chad.]

33. Lantsberger PA, Glass LS, Ottmar E. The Washington state workers' compensation system: a case study. Clin Occup Environ Med. 2004;4(2);309-22. [A research project to evaluate optimal methods of quality control and cost control and maximize worker and employer satisfaction.]

34. Cloeren M, Mallon TM. Managing workers' compensation costs in the military setting: the Army's story. Clin Occup Environ Med. 2004;4(2):323-39 [A study that reports the current status, including claims, costs, and lost-day trends, of the Army's workers' compensation program.]

35. Richardson S, Windau J. Fatal and nonfatal assaults in the workplace, 1996-2000. Clin Occup Environ Med. 2003;3(4):673-89. [A study of the Bureau of Labor Statistics (BLS) surveillance data for 1996 through 2000 to update and analyze trends in fatal and nonfatal assaults in the workplace.]

36. Foley M, Silverstein BA. The economic burden of nonfatal workplace assaults in Washington State. Clin Occup Environ Med. 2003;3(4):691-709. [An analysis of the counts and rates for events related to assaults and violent acts.]

37. Ferber D. Authors turn up heat over disputed paper. Science (Occupational Medicine). 2004;304:1891.

38. Greenberg M. Internet message from Morris Greenberg (London) to Joe LaDou, June 19, 2004.

39. LaDou J. Internet message from Joe LaDou to Catherine Bewick of Elsevier Science, June 17, 2004.

40. Axelson O, Balbus JM, Cohen G, et al. Re: Regulatory Toxicology and Pharmacology. Int J Occup Environ Health. 2003;9(4): 386-9; author reply 389-90.

41. Clapp RW. Mortality among US employees of a large computer manufacturing company: 1969-2001. Environ Health. 2006;5:30. <http://www.ehjournal.net/content/pdf/1476-069x-5-30.pdf $>$.

42. Harding A. IBM cancer data published. Disputed study sees the light of day after a lengthy controversy. The Scientist, October 26, 2006, News.

43. Armour S. Cancer fears persist among IBM workers. USA Today. November 26, 2006. <http://www.usatoday.com/printedition/ money/20061127/ibmworkers.art.htm>. 